\title{
Perceptions and Preferences of Urban Greenspaces: A Literature Review and Framework for Policy and Practice
}

\author{
Leila Mahmoudi Farahani*, Cecily Maller \\ RMIT University, 124 Latrobe Street, Melbourne VIC 3000, Australia
}

\begin{abstract}
The ever-increasing process of urbanisation across the globe has major implications for the environment, biodiversity and health and wellbeing of urbanites. Urban greenspaces are considered a promising planning tool in tackling some of the problems associated with urbanisation such as pollution and urban heat island effects. It is, therefore, important to understand what encourages the extent to which urban dwellers interact with or use greenspaces. Perceptions and preferences are different ways of exploring how users interact with greenspace, but they are traditionally considered separately in extant research. The aim of this literature review is to synthesise the existing evidence for both perceptions of and preferences for greenspaces, highlighting crossovers and synergies between these two approaches. Drawing on a review of literature found in three online databases - EBSCOhost Web, Taylor and Francis Online and Elsevier -, the paper proposes a framework for understanding perceptions of and preferences for greenspaces which can assist policy makers and planners to develop and design greenspaces with higher efficiency and use or improve existing ones, ultimately improving the liveability of urban environments.
\end{abstract}

\section{Keywords:}

greenspace, parks, lived experiences, liveability, literature review

*Corresponding author. Email: leila.farahani@rmit.edu.au

(C) The Authors. 2018. Landscape Online. This is an Open Access article distributed under the terms of the Creative Commons Attribution License (http://creativecommons.org/licenses/by/4.0), which permits unrestricted use, distribution, and reproduction in any medium, provided the original work is properly cited. 


\section{Introduction}

Currently half of the world's population lives in urban areas and this number is expected to rise to $70 \%$ by 2050 (United Nations, 2014). This ever-increasing process of urbanisation across the globe will have major environmental implications as well as affect the health and wellbeing of urban residents (Kabisch, Qureshi, \& Haase, 2015; Lin, Fuller, Bush, Gaston, \& Shanahan, 2014). There is growing recognition of urban greenspaces as a promising planning tool in offsetting some of the problems associated with urbanisation, including biodiversity loss and heat island effects (Kendal, Williams, \& Williams, 2012; Smith, Thompson, Hodgson, Warren, \& Gaston, 2006).

Urban greenspaces are usually defined as publicly owned and accessible open spaces within urban and peri-urban areas that are wholly or partly covered by considerable amounts of vegetation (Conedera, Del Biaggio, Seeland, Moretti, \& Home, 2015; Hadavi, Kaplan, \& Hunter, 2015; Pillay \& Pahlad, 2014). Parks, woodlands, nature conservation areas, gardens and sports fields are among different types of urban greenspaces. These areas can either be humanmodified with a designed or planned character (formal greenspaces), or have a more natural or unplanned character (informal greenspaces) (Farahani \& Maller, 2018; Schipperijn, Stigsdotter, Randrup, \& Troelsen, 2010; Wright Wendel, Zarger, \& Mihelcic, 2012).

Greenspaces are an important indicator of the liveability of urban areas and are associated with a range of benefits from a broad cross-section of literature. The health benefits of greenspaces and access to nature have been widely studied over the last two decades (Lee \& Maheswaran, 2011; Townsend, Maller, St Leger, \& Brown, 2003) and include positive effects on both physical (Shanahan et al., 2015) and mental health and wellbeing (Alcock, White, Wheeler, Fleming, \& Depledge, 2014). Social cohesion (Groenewegen, Van den Berg, De Vries, \& Verheij, 2006) and economic benefits (Tyrvainen, 1997) are less studied, but are also important aspects of greenspaces (Keniger, Gaston, Irvine, \& Fuller, 2013). Environmental benefits such as ecosystem services, improving microclimate, reducing air pollution, mitigating noise and biodiversity conservation are also widely acknowledged (Kong, Yin, Nakagoshi, \& Zong, 2010; Shanahan et al., 2015).

With mounting empirical evidence on the importance of greenspaces for human health and wellbeing, it has become increasingly important to identify what encourages urban residents to interact with and use greenspaces (Hitchings, 2013). Depending on the type and intensity of interactions and the characteristics of greenspaces, residents may experience different benefits from various forms of greenspace. While some of the benefits of urban greenspaces have positive effects on the wider neighbourhood (such as improved air quality and noise reduction), health benefits such as from physical activity and restorative effects depend on visitation.

Previous research has found that people hold complex and uncertain 'half sought and half feared' perceptions of greenspaces (Jim \& Shan, 2013, p. 123). While residents value their benefits, they sometimes associate greenspaces with feelings of insecurity and crime. Residents who have positive perceptions of greenspaces and find them pleasant and safe are more likely to use them (Jim \& Shan, 2013; Maller \& Farahani, 2018).

Although positive perceptions of greenspace are shown to have potential to enhance greenspaces visitation and enhance the benefits (Jim \& Shan, 2013), the provision of urban greenspaces in many cities - especially in developing countries takes place without much attention to residents' wishes regarding location, design, qualities and management: 'Professional assumptions that lack theoretical or empirical basis commonly dominate decisions on urban greenspaces' (Jim \& Chen, 2006, p. 338). Without public support and involvement, urban greenspaces could fail to meet residents' preferences and needs, exclude certain groups, and 
attract 'undesirable' activities; in extreme cases, they can be abandoned (Farahani \& Maller, 2018; Farahani, Maller, \& Phelan, 2018; Jim \& Chen, 2006, p. 338). One explanation is that the same setting may be perceived differently by greening professionals and residents (Kaplan \& Kaplan 1989). A recent study has found that positive perceptions of greenspaces are important indicators of neighbourhood satisfaction (Douglas, Russell, \& Scott, 2018). Therefore, understanding residents' perceptions of and preferences for greenspaces and engaging them in the planning process can potentially bring more benefits to local residents (Adegun, 2018; Jim \& Chen, 2006; Keith, Larson, Shafer, Hallo, \& Fernandez, 2018; Marcus \& Francis, 1997) and boost the success of greening developments and interventions. Research on perceptions and preferences has therefore gained increasing recognition among scholars (De La Barrera, Reyes-Paecke, Harris, Bascuñán, \& Farías, 2016; Jim \& Chen, 2006).

In spite of their significance, the terms 'perceptions' and 'preferences' have not been clearly defined and have been used interchangeably, or without distinction, in the literature (Swanwick, 2009). There are also similar terms, including 'orientation' and 'attitude' that have been used similarly to perceptions and preferences (Buchel \& Frantzeskaki, 2015 , p. 170). Considering the high degree of overlap in the use of preferences and perceptions in work on greenspaces, the aim of this literature review is to synthesise existing evidence, clarify the differences and similarities between these terms and identify what attributes affect them. In doing so, an integrated conceptual framework on the attributes and variables that influence residents' perceptions of and preferences for urban greenspaces is developed by drawing on literature from a range of disciplines including landscape architecture, planning, geography and environmental psychology. Compiling all indicators and attributes together can facilitate a better understanding of how greenspaces are percieved and used; how human-greenspace interaction can be investigated; and how greenspaces can be effectively developed or maintained. The framework can, therefore, be used to inform future research and work on greenspaces and greening interventions to enhance neighbourhoods liveability and residents' quality of life. The next section presents the methodology and preliminary analysis of the articles located for review. This is followed by a discussion on the meaning and implications of perceptions and preferences. The final section is assigned to the study of the proposed framework and the discussion of how it can be used effectively for future research and greenspace design.

\section{Review methodology and findings}

First, searches were performed in three leading online databases - EBSCOhost Web, Taylor and Francis Online and Elsevier - for all articles published until September 2016, using combinations of the terms 'green space' OR 'greenspace' AND 'preference' OR 'perception'. The three databases were chosen since they include highly ranked landscape, greening and planning journals and publish peer-reviewed articles. Including other potential databases was beyond the scope of this study but can be considered for future research.

Overall, 1314 articles were located in all three databases. An initial scan to examine the relevance of the research was conducted by reviewing the article's title and subtitle, reducing the number of articles selected for review in more detail to 67 . Searching Taylor and Francis Online alone located just over one thousand articles. The considerable reduction of articles accross all three databases was because of the lack of direct relevance to perceptions of and preferences for greenspaces.

Abstracts of the remaining 67 articles were checked to meet three criteria: 1) a focus on perceptions or preferences of greenspaces; 2) the inclusion of public or formal greenspaces; and 3) the paper was published in English. The number of articles meeting these criteria was 45 . Percentages of the number of remaining articles located in each of abovementioned databases can be seen in Figure 1 . 


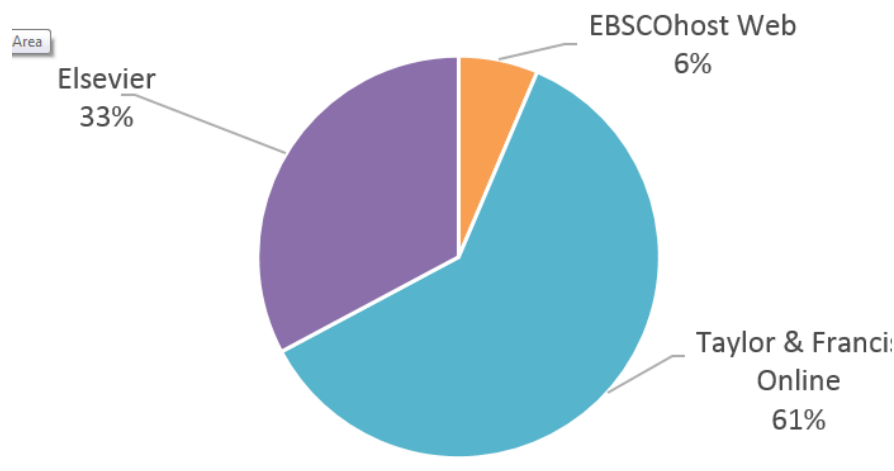

Figure 1: Percentages of articles on preferences for and perceptions of greenspaces based on the 45 located articles

The final selection of articles - the 45 articles found through initial searches - was analysed in terms of the year of publication, the geographical context and the methodology of the research. Both qualitative and quantitative methods were included in the review. All articles were published after the year 2000, indicating attention to users' perception of and preferences for urban greenspaces began only in the last decade. However, as can be seen in Figure 2, the number of studies on preferences for and perceptions of greenspaces has significantly increased since 2010. About $40 \%$ of the articles were published from 2015 to September 2016. The fact that the publication on preferences for and perceptions of urban greenspaces has recently gained momentum suggests that existing urban parks and greenspaces may have been established without consideration of residents' perceptions and attitudes towards them, or that this topic has only recently been of interest to researchers.

The research in the review originated from five continents (Fig. 3). The largest contribution is from Europe $(n=21)$ (Fig. 3) with half of the studies conducted in the UK $(n=6)$ or Sweden $(n=5)$ (Fig. $4)$. This was followed by Asia ( $n=9)$, with the most studies conducted in China ( $n=6)$ (Fig. 4). America $(n=6)$, Australia $(n=4)$, and Africa $(n=2)$ have the lowest number of studies amongst the reviewed articles (Fig. 3). Three articles compared studies in different countries which were referred to as 'multiple case studies'.

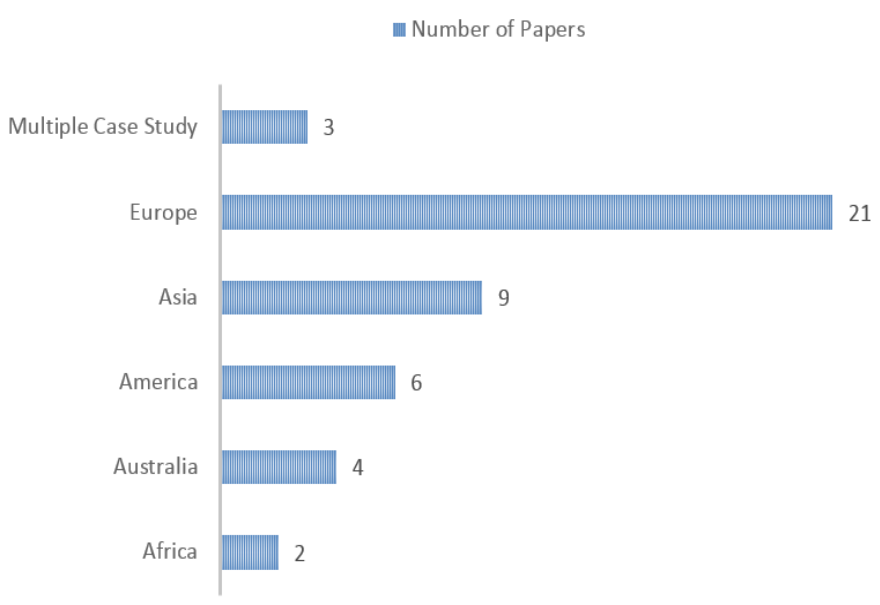

Figure 3: Articles published on perceptions and preferences of greenspaces based on the location of their case study

\section{Number of Papers}

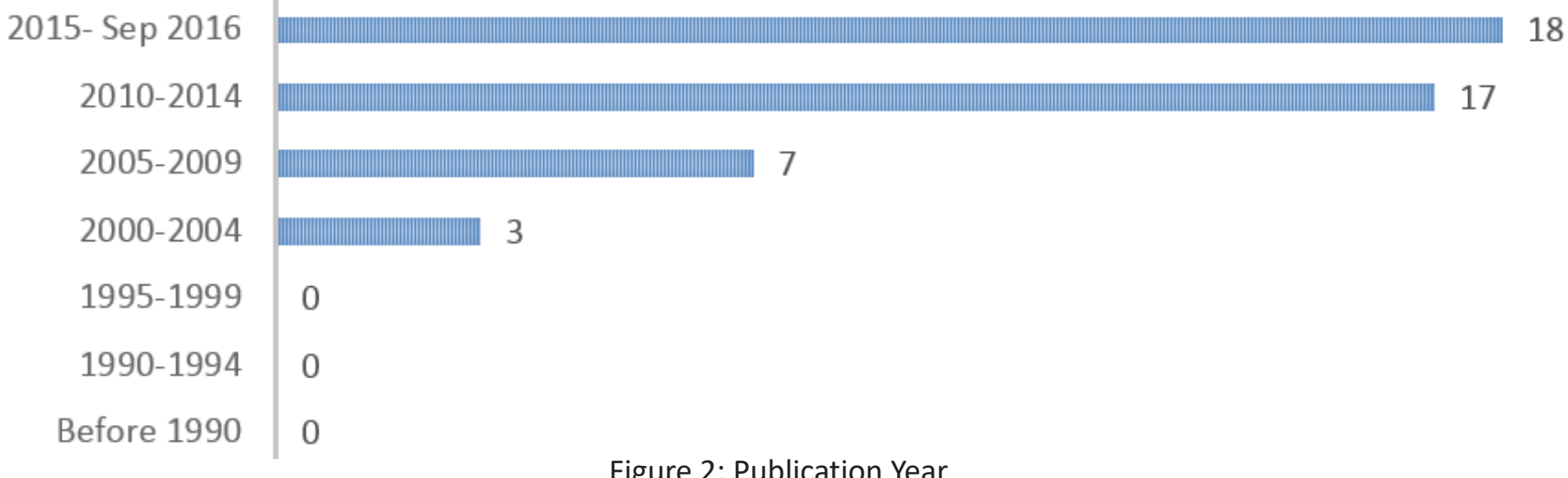

Figure 2: Publication Year 

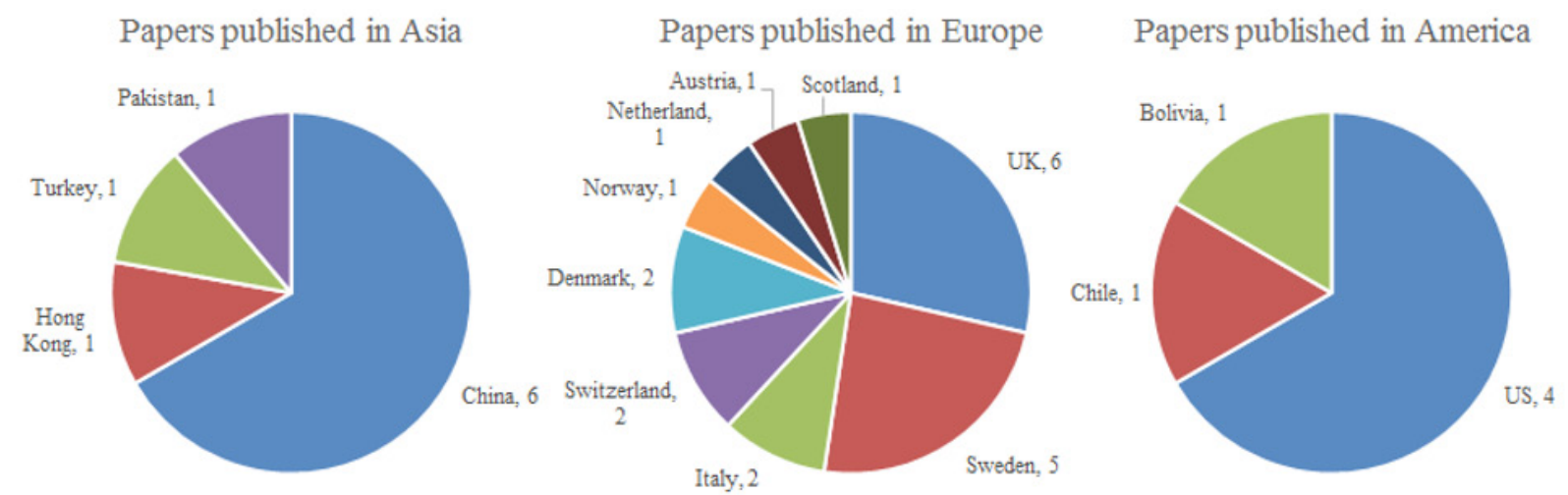

Figure 4: Articles published on perceptions of and preferences for greenspaces based on the location of their case study

These findings show that there are fewer studies in Africa, America (other than the US) and Asia (other than China) (Fig. 3).

As can be seen in Figure 5, surveys of users and visitors have been the most popular methodology in studying perceptions of and preferences for urban greenspaces. 'Multi-method' refers to the articles that have utilised more than one technique for data collection. Ten papers used a multiple data-collection technique (e.g. observations and interviews). GIS and observations were commonly integrated with other methodologies such as surveys or interviews. The fact that existing research is more focused on quantitative approaches suggests an opportunity for more qualitative methodologies for studying preferences for and perceptions of greenspaces (De La Barrera et al., 2016; Hitchings, 2013).

To ensure the literature review was comprehensive, a snowballing method was conducted and the references of the remaining articles were explored to locate relevant literature that were potentially missed from the initial searches within the abovementioned databases. Additional articles were also compared and checked against the criteria increasing the final number of articles reviewed in detail to 78. However, the analysis of publication year, case study location and research methodology was conducted only on the 45 articles located from

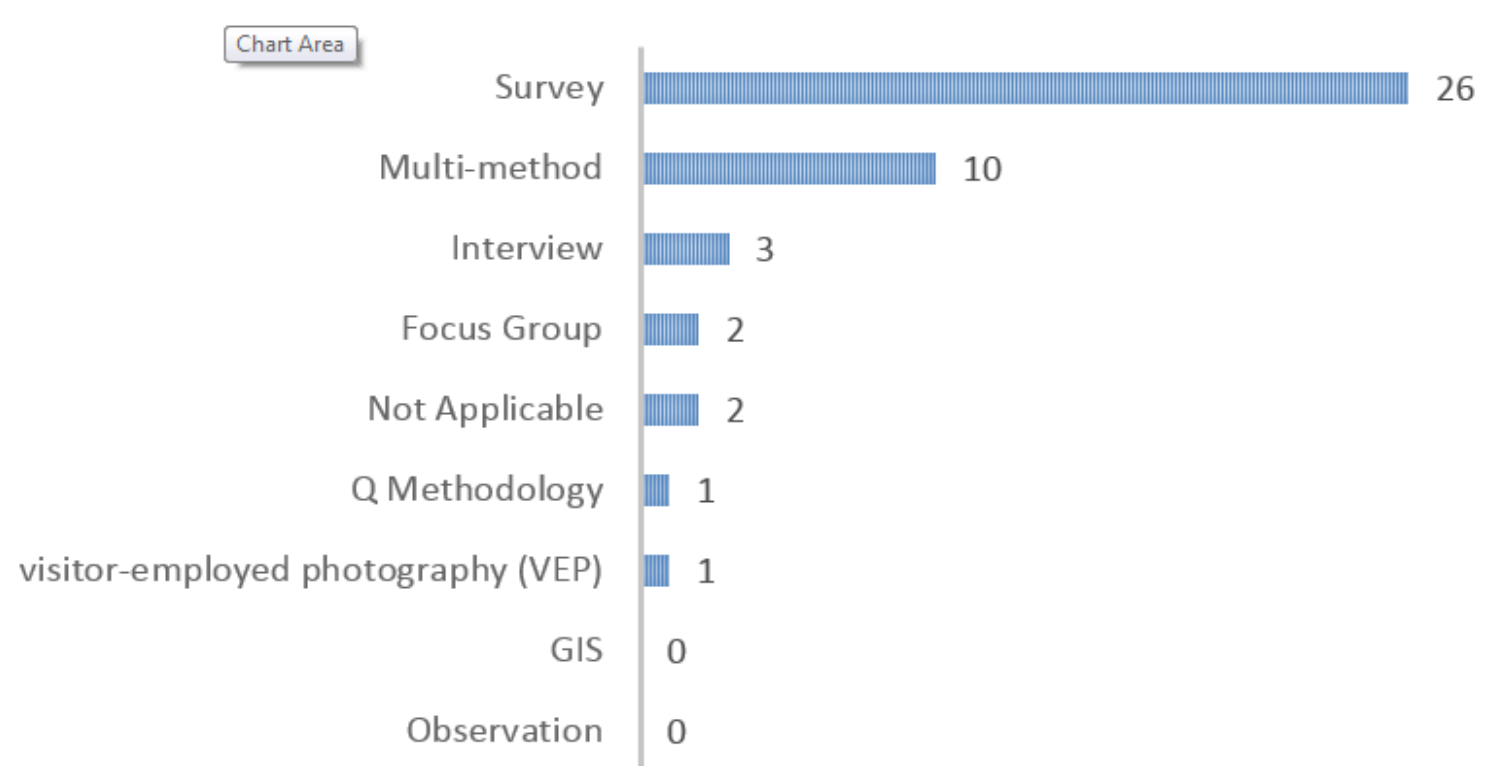

Figure 5: The methodology used in understanding greenspaces perceptions and preferences 
the three key online databases as the additional articles located via snowballing were from a wider range of sources. There is an opportunity for future research to explore the occurrence, frequency and location of papers on perceptions and/or preferences of greenspace in other databases not covered in this study. The following section offers an overview of perceptions and preferences and their implication in the reviewed articles.

\section{Preferences and perceptions: meanings and implications}

Before introducing the framework, this section of the paper defines 'preferences' and 'perceptions' as used in the literature on greenspaces. Swanwick (2009, p. 63) defines 'preference' as 'liking one area of land or landscape better than another'. According to R. Kaplan and Kaplan (1989), effective functionality of a setting or an environment is a significant attribute in individual preferences: 'Preference can be expected to be greater for settings in which an organism is likely to thrive and diminished for those in which it may be harmed or rendered ineffective' (R. Kaplan \& Kaplan, 1989, p. 10). Thus humans, like other animal species, are far more likely to prefer a setting in which they can function effectively. R. Kaplan and Kaplan (1989, p. 10) argue that preference 'suggests the decorative rather than the essential, the favored as opposed to the necessary'.

'Perception' refers to both sensual - often visual - experiences of greenspaces and to how residents assign meaning and value to them (Swanwick, 2009). User's perceptions of greenspaces can be explored through the lens of how such spaces are appreciated, such as whether or not they are preferred compared to other spaces (De La Barrera et al., 2016). As Jay and Schraml (2009, p. 285) write: 'Every individual structures the experiences he or she has with their environment in schemata. Perception, as the subjective interpretation of reality, can be regarded as the totality of schemata that individuals construct through interactions with their environment'.
Physical qualities of a setting are not the only attributes that impact visitors' perceptions. The values, experiences and socio-cultural conditioning of users also affect how an environment is perceived (Scott, 2003). Therefore, understanding individual perceptions of a setting is complex and multifaceted.

Perceptions and preferences are closely related. Preference indicates a comparison: either between the existing situation/setting and an ideal one, or between two or more situations/settings (for instance, two types of greenspaces or two parks). Perception, however, refers to the subjective understanding of and feelings towards an existing entity, which express what a person likes or dislikes or thinks and feels about it. According to R. Kaplan and Kaplan (1989), preference assessments are based on perceptions.

Nature orientation referring to how much residents value nature is found to be a stronger determinant of park visitation compared to opportunity (Lin et al., 2014). Therefore, measures to increase positive perceptions of greenspaces and residents' connection to nature can be more effective than increasing greenspaces availability and accessibility in neighbourhoods.

Perceptions of and preferences for greenspaces have been studied across a broad range of disciplines including landscape architecture, planning, geography, public health, environmental sciences, environmental psychology and agricultural sciences and forestry (Table 2). According to the reviewed articles, preference studies have been mostly conducted within disciplines such as landscape architecture, planning and geography, whereas the perception of greenspaces has been mostly studied within environmental psychology and landscape architecture. This disciplinary categorisation is based on the journals' scope and the main disciplines of the reviewed articles. The present study brings these studies together and develops a framework that can be used across disciplines for a better understanding of users' experiences of greenspaces. The following section outlines how the framework is developed. 


\section{Framework methodology}

The articles from the literature review were imported to NVivo - a computer-assisted qualitative data analysis software - and constant comparison analysis was used for investigation and developing the framework. The process of constant comparison is a method in developing and classifying codes that are then compared and contrasted with one another (Ezzy, 2013). The process of coding identified recurring categories existing among the articles on greenspace preferences and perceptions and their underlying or explanatory features. The framework proposed in this section is formed by a classification of these categories to construct a model that allows an understanding of linkages between perception and/or preferences and qualities of greenspaces based on existing knowledge.

Two of the key existing frameworks on benefits of parks and the classification of park attributes are developed by Bedimo-Rung, Mowen, and Cohen (2005, pp. 160-163). One of these frameworks is on the relationship between parks and physical activity and the other one focuses on the environmental classification of park attributes. Integrating these frameworks and taking them further, Stodolska, Shinew, Acevedo, and Izenstark (2011, p. 118) proposed another framework for park characteristics and benefits of park visitation among minorities. Their framework has four main components:

1) park space - explaining park characteristics;

2) individual user characteristics;

3) neighbourhood characteristics; and

4) benefits of park visitation.
Stodolska et al.'s (2011) framework is one of the most comprehensive frameworks that includes greenspaces attributes and individual user characteristics. Therefore, to facilitate the thematic analysis and coding process, the framework developed by Stodolska et al. (2011, p. 118) was utilised and the themes under park space and individual user characteristics were adopted as initial nodes in NVivo (Table 1). Nodes in NVivo are the containers for coding. Nodes are usually made for each topic or concept to be stored (Bazeley \& Richards, 2000). Next, based on the reviewed articles and through the recurring process of coding, the adopted nodes were modified to reflect the literature on greenspaces preferences and perceptions.

The process of coding commenced with four initial parent nodes: perceptions, preferences, greenspaces and individual characteristics. The child nodes or themes under individual characteristics and greenspaces were iniated based on Stodolska et al.'s (2011, p. 118) framework and they were modified based on the reviewed articles. Two themes of neighbourhood characteristics and greenspace benefits from Stodolska et al.'s (2011, p. 118) framework were disregarded as they weren't fully relevant to greenspaces perceptions and preferences. Neighbourhood characteristics include qualities of neighbourhoods such as walkability, safety and aesthetics and benefits refer to various forms of benefits residents gain from visiting parks. The references column in Table 1 shows the number of times each theme was referred to in the reviewed articles.

Table 1: NVivo nodes (generated themes), sources (number of articles) and references (the number of times themes were referred to) (Source: authors)

\begin{tabular}{|l|r|r|}
\hline Nodes & Sources & References \\
\hline Perceptions & 8 & 12 \\
\hline Cultural background & 2 & 2 \\
\hline Orientation affinity - visitors value - Attitudes to nature & 2 & 6 \\
\hline Perceived Accessibility & 3 & 1 \\
\hline perceived functionality & 3 & 5 \\
\hline Perceived restorativeness & 1 & 11 \\
\hline Perceived safety & & 8 \\
\hline
\end{tabular}




\begin{tabular}{|c|c|c|}
\hline Meaning & 1 & 1 \\
\hline Perceived sensory dimensions & 4 & 16 \\
\hline SES & 2 & 3 \\
\hline Preferences & 9 & 13 \\
\hline Green space & 5 & 7 \\
\hline Accessibility and abundance & 17 & 41 \\
\hline biodiversity & 4 & 13 \\
\hline Condition & 1 & 1 \\
\hline Congestion-overcrowding & 3 & 5 \\
\hline Incivilities & 2 & 3 \\
\hline Maintenance & 13 & 18 \\
\hline Facilities and programs & 14 & 25 \\
\hline Trail & 1 & 5 \\
\hline Management & 2 & 2 \\
\hline Safety & 14 & 33 \\
\hline Sensory Dimensions - Quality and attractiveness & 6 & 6 \\
\hline Naturalness & 16 & 33 \\
\hline Vegetation & 9 & 25 \\
\hline Landscape design & 1 & 1 \\
\hline Possibilities for overview and control & 1 & 1 \\
\hline Vegetation character and maintenance & 1 & 1 \\
\hline Vegetation Density & 3 & 9 \\
\hline Visual Aesthetic Quality & 5 & 9 \\
\hline Size & 5 & 9 \\
\hline TYPE & 5 & 5 \\
\hline Walkability-transport network infra structure & 4 & 4 \\
\hline Individual Characteristics & 11 & 13 \\
\hline AGE & 8 & 12 \\
\hline childhood & 4 & 6 \\
\hline ecological knowledge and educational background & 6 & 7 \\
\hline Gender & 10 & 25 \\
\hline Green Political Parties & 1 & 1 \\
\hline Marital Status & 1 & 1 \\
\hline Migration - cultural background & 10 & 44 \\
\hline Activities and use & 0 & 0 \\
\hline facilities & 0 & 0 \\
\hline safety & 0 & 0 \\
\hline sociability & 0 & 0 \\
\hline type & 0 & 0 \\
\hline Place of residence & 3 & 4 \\
\hline SES & 7 & 7 \\
\hline Values & 5 & 11 \\
\hline Types of activities & 6 & 7 \\
\hline
\end{tabular}


Figure 6 illustrates the proposed framework of this study which includes four main domains:

1) greenspace and its characteristics (positioned on the right side of the framework and connected to perceptions and preferences);

2) perceptions (placed at the top of the framework and includes sensory dimensions, perceived qualities and visitors attitudes);

3) preferences (located at the bottom side and includes the type of activities); and

4 ) individual characteristics (left end of the framework and similar to greenspaces, are connected to both perceptions and preferences).
A list of references in relation to these domains and attributes can be accessed in Table 2 .

The framework developed in this study is more inclusive compared to the one Stodolska et al. (2011, p. 118) developed which focused solely on minorities. Additionally, the main focus of the framework proposed in this paper is on the preferences and perceptions of greenspaces, compared to Stodolska et al.'s (2011, p. 118) which was on park visitation. Therefore, while there are some overlaps between the two frameworks (in individual characteristics and greenspaces characteristics), the two remaining sections (perceptions and preferences) are different. The following section discusses the proposed framework in depth.

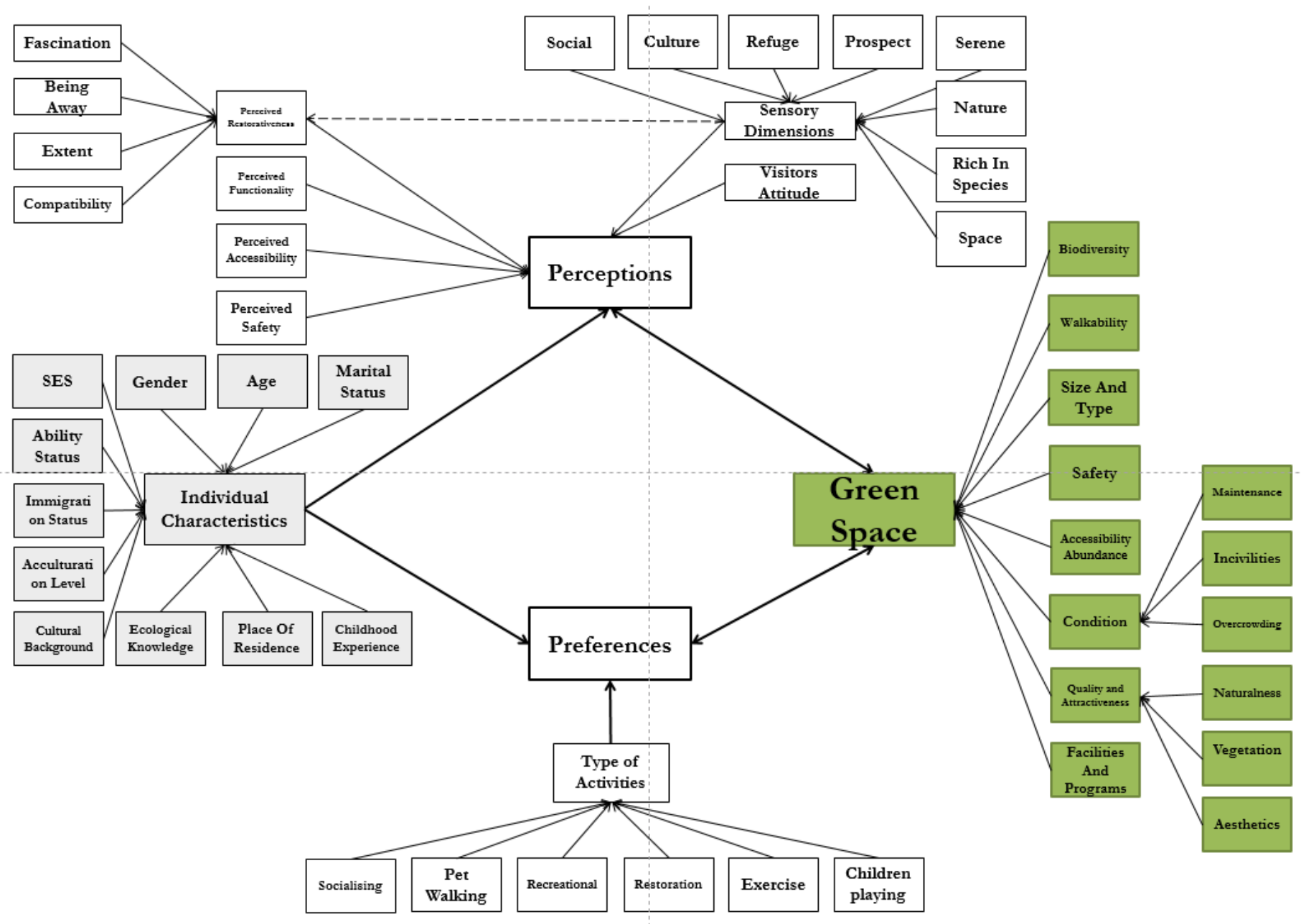

Figure 6: Perception of and preferences for greenspaces framework (Source: authors) 


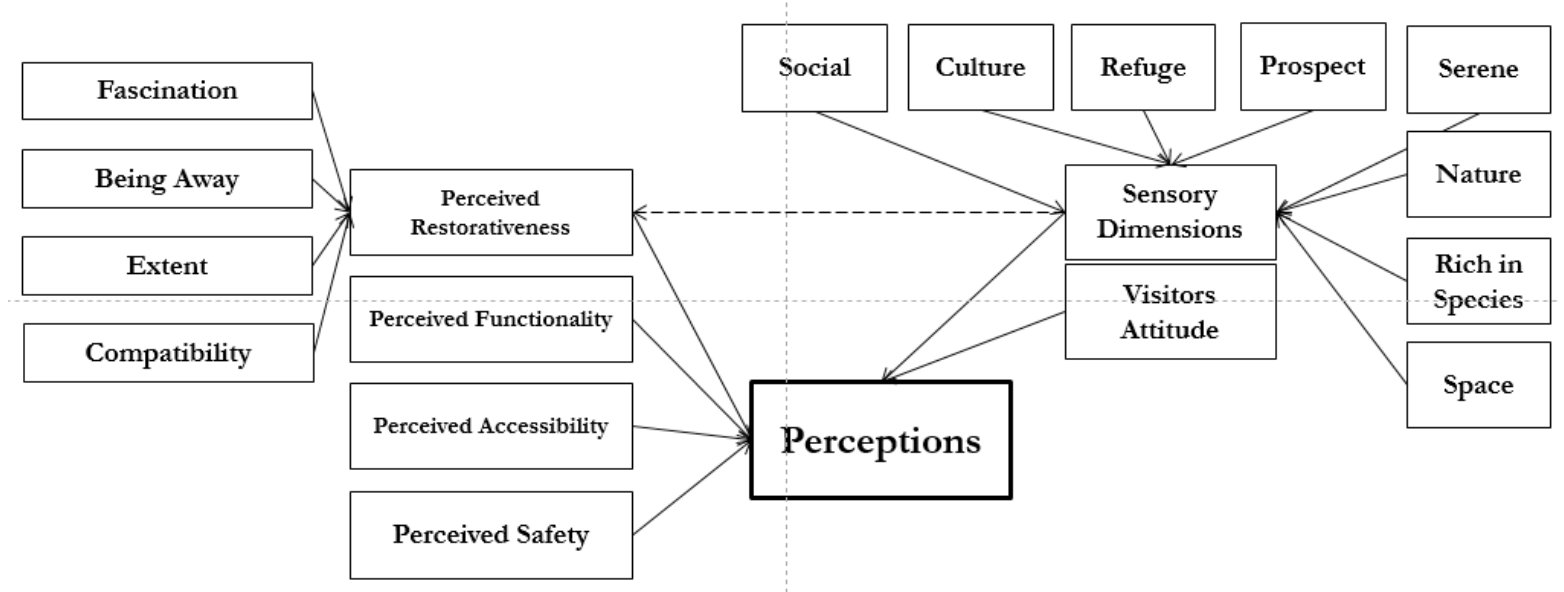

Figure 7: Perception of greenspaces

5 A framework for understanding perception of and preferences for greenspaces

The proposed framework suggests that both preferences for and perceptions of greenspaces are each determined in part by individual characteristics and the characteristics of greenspaces. However, where preferences and perceptions differ is that preferences are also determined by the type of activities, and perceptions of greenspaces are determined by the sensory dimensions and perceived qualities. This explains why perceptions of greenspaces is a major area of interest within the field of environmental psychology where sensual experiences of users are investigated (Grahn \& Stigsdotter, 2010; Peschardt \& Stigsdotter, 2013; Qiu \& Nielsen, 2015) (see extract in Fig. 7).

According to the framework (Fig. 6), perceptions of greenspaces are not particularly dependent on the type of activity. For instance, if a park is perceived to be unsafe, the type of activity that users wish to do, does not make a huge difference. Whereas, preferences for greenspaces are partly shaped by the type of activity that greenspaces are used for. For instance, preferences for greenspaces used for exercising can be different to those used for socialising as shown in an extract of the framework in Figure 8.

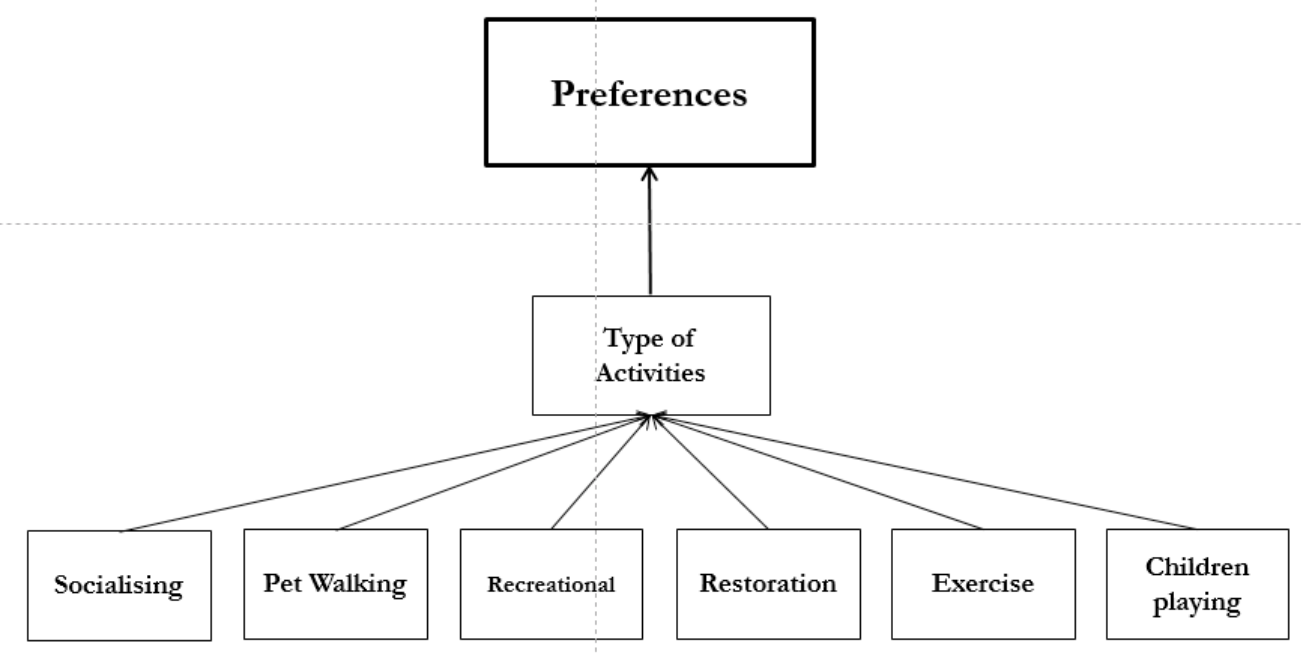

Figure 8: Type of activities and its contribution to greenspaces preferences 


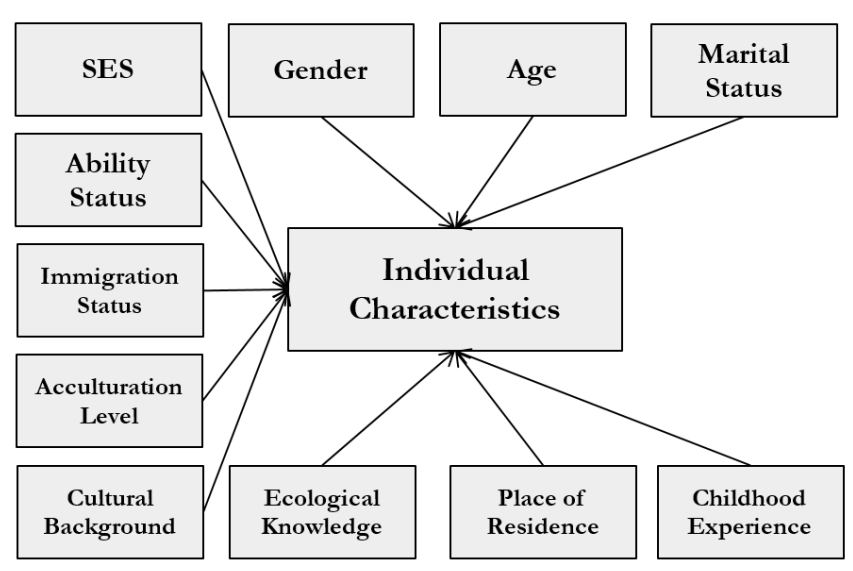

Figure 9: Individual characteristics

Both perceptions of and preferences for greenspaces may differ according to a multitude of variables relating to visitors or users $(\mathrm{H}$. Ozguner \& Kendle, 2006; Schipperijn et al., 2010; Wan \& Shen, 2015; R. Wang, Zhao, \& Liu, 2016; W. Zhang, Yang, Ma, \& Huang, 2015): 'A given setting is likely to be experienced differently by different people and it is through these manifold experiences that urban green spaces gain their nuanced meaning and the multiple values that transform them from space to place' (Qiu \& Nielsen, 2015, p. 835). Therefore, the provision of greenspaces should aim directly at visitors and users (Jim \& Chen, 2006). Age, gender, immigration status and cultural background are among the most recognised components of individual characteristics in relation to greenspaces preferences and perceptions as shown in an extract of the framework in Figure 9.

The qualities of greenspaces are closely linked with improved visitors experiences and therefore individuals' perceptions and preferences (GilesCorti et al., 2005; Paul H. Gobster, 1998): 'A park's physical location and design may determine whether it becomes an unwanted urban vacuum or a valued neighbourhood space that fosters social interaction' (D. Wang, Brown, Liu, \& Mateo-Babiano, 2015 , p. 94). The qualities of greenspaces that have been discussed in the literature on residents' perceptions and preferences are biodiversity, walkability including the number, type and quality of paths, size and type, safety, accessibility and abundance, condition, quality and attractiveness, and facilities and programs as shown in an extract of the framework in Figure 9. Accessibility, safety facilities, and programs are amongst the most studied attributes of greenspaces.

As mentioned above perceptions and preferences are different ways of understanding how users experience and interact with greenspace; yet traditionally, they are separately studied and the reason for this division is unclear. Yet the focus of both types of studies are residents and how they interact with greenspaces. The aims also seem to be similarly about how to improve the quality of greenspaces and design them in line with residents' needs and preferences. And as the framework illustrates (Figure 6) individual characteristics and greenspaces characteristics are linked to both perceptions and preferences.

But an important question to consider is when to focus on preferences for greenspaces and when perceptions of such spaces should be considered. As perceptions are about sensual experiences of existing

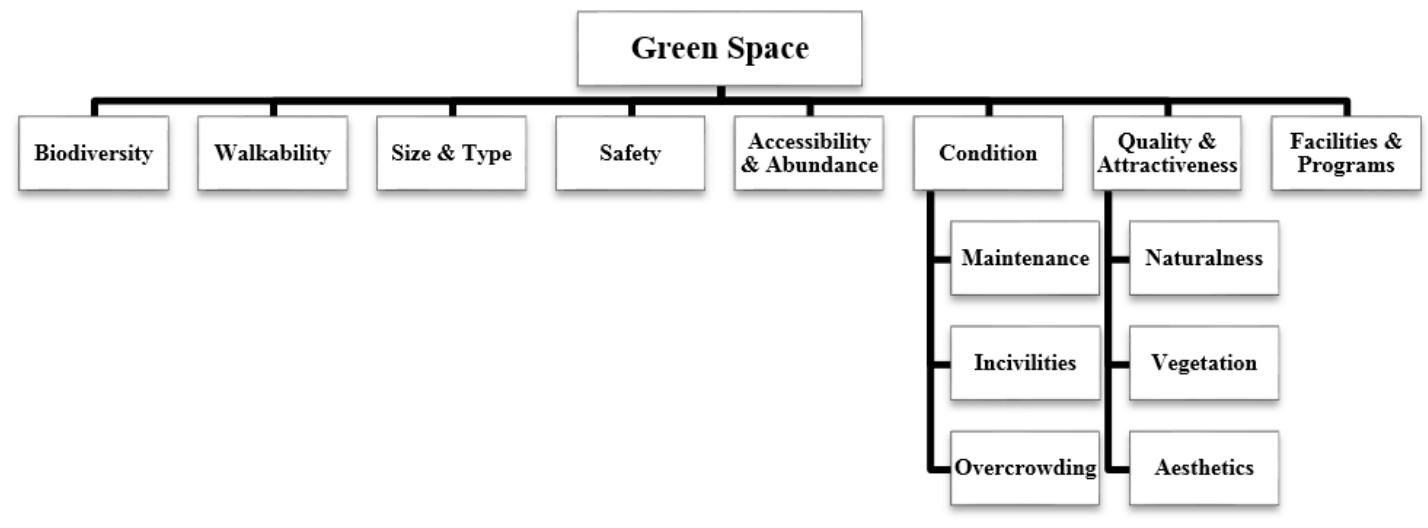

Figure 9: Individual characteristics 
spaces, perception studies are more worthwhile for intervention sites and projects that aim to improve extant conditions of greenspaces. Perception studies can assess how well a setting such as a greenspace performs and what areas can be improved. For instance, perceptions of safety and accessibility of a park affects the level of residents' interaction with it. Therefore, improving its safety and accessibility could contribute to its visitation. Preference studies, on the other hand, are not only important for intervention projects, but also have implications for almost every greening project. Therefore, a better understanding of the demographics of the local population and residents' preferences can result in a better design of future greenspaces.

The framework proposed in this study acknowledges that perceptions and preferences are two different terms with distinct meanings and implications; however simultaneous investigation of both perceptions of and preferences for greenspaces can bring interdisciplinary studies together to achieve a higher quality urban green infrastructure. The proposed framework can, therefore, be used by scholars, practitioners and professionals in design studies to understand residents' viewpoints about their extant local greenspaces and variables that can improve them or affect future greening developments.

For example, the framework can be used in community consultation sessions focusing on greening actions to enliven potential changes in qualities of greenspaces that can encourage visitation, use and positive perceptions towards them. It can also assist in understanding how individual and cultural differences of various communities might affect their perceptions, preferences and use of greenspaces. Therefore, understanding the structure of communities and what they need is crucial to successful greening developments. The framework also highlights that while perceptions and preferences are both closely linked to greenspace qualities and individual characteristics, they are different terms with different implications which should be addressed in future greening research and community studies.

Table 2: Key references regarding the developed framework

\begin{tabular}{|c|c|c|}
\hline \multirow[t]{3}{*}{$\begin{array}{c}\text { Individual } \\
\text { Characteristics }\end{array}$} & Age & $\begin{array}{l}\text { Kaczynski, Potwarka, Smale, \& Havitz, 2009; Kemperman \& } \\
\text { Timmermans, 2006; Kienast, Degenhardt, Weilenmann, Wäger, \& } \\
\text { Buchecker, 2012; Mowen, Payne, \& Scott, 2005; Payne, Mowen, } \\
\text { \& Orsega-Smith, 2002; Qureshi, Breuste, \& Jim, 2013; Rodiek, } \\
\text { 2002; Schetke, Qureshi, Lautenbach, \& Kabisch, 2016; Schipperijn } \\
\text { et al., 2010; Talbot \& Kaplan, } 1991\end{array}$ \\
\hline & Gender & $\begin{array}{l}\text { Carter \& Horwitz, 2014; Caula, Hvenegaard, \& Marty, 2009; Chen, } \\
\text { Adimo, \& Bao, 2009; Conedera et al., 2015; Ellaway \& Macintyre, } \\
\text { 2001; Jay \& Schraml, 2009; Jorgensen, Hitchmough, \& Calvert, } \\
\text { 2002; Kaczynski et al., 2009; Mowen et al., 2005; Ode, Fry, Tveit, } \\
\text { Messager, \& Miller, 2009; Ode Sang, Knez, Gunnarsson, \& } \\
\text { Hedblom, 2016; Pillay \& Pahlad, 2014; Schipperijn et al., 2010; } \\
\text { Tyrvainen, } 1997\end{array}$ \\
\hline & $\begin{array}{l}\text { Immigration } \\
\text { status and } \\
\text { Cultural } \\
\text { background }\end{array}$ & $\begin{array}{l}\text { Buijs, Elands, \& Langers, 2009; Carter \& Horwitz, 2014; Edwards } \\
\text { \& Weldon, 2006; Gramann, Floyd, \& Saenz, 1993; Jay \& Schraml, } \\
\text { 2009, 2014; Jim \& Chen, 2006; Madureira, Nunes, Oliveira, } \\
\text { Cormier, \& Madureira, 2015; Halil Ozguner, 2011; Payne et al., }\end{array}$ \\
\hline
\end{tabular}




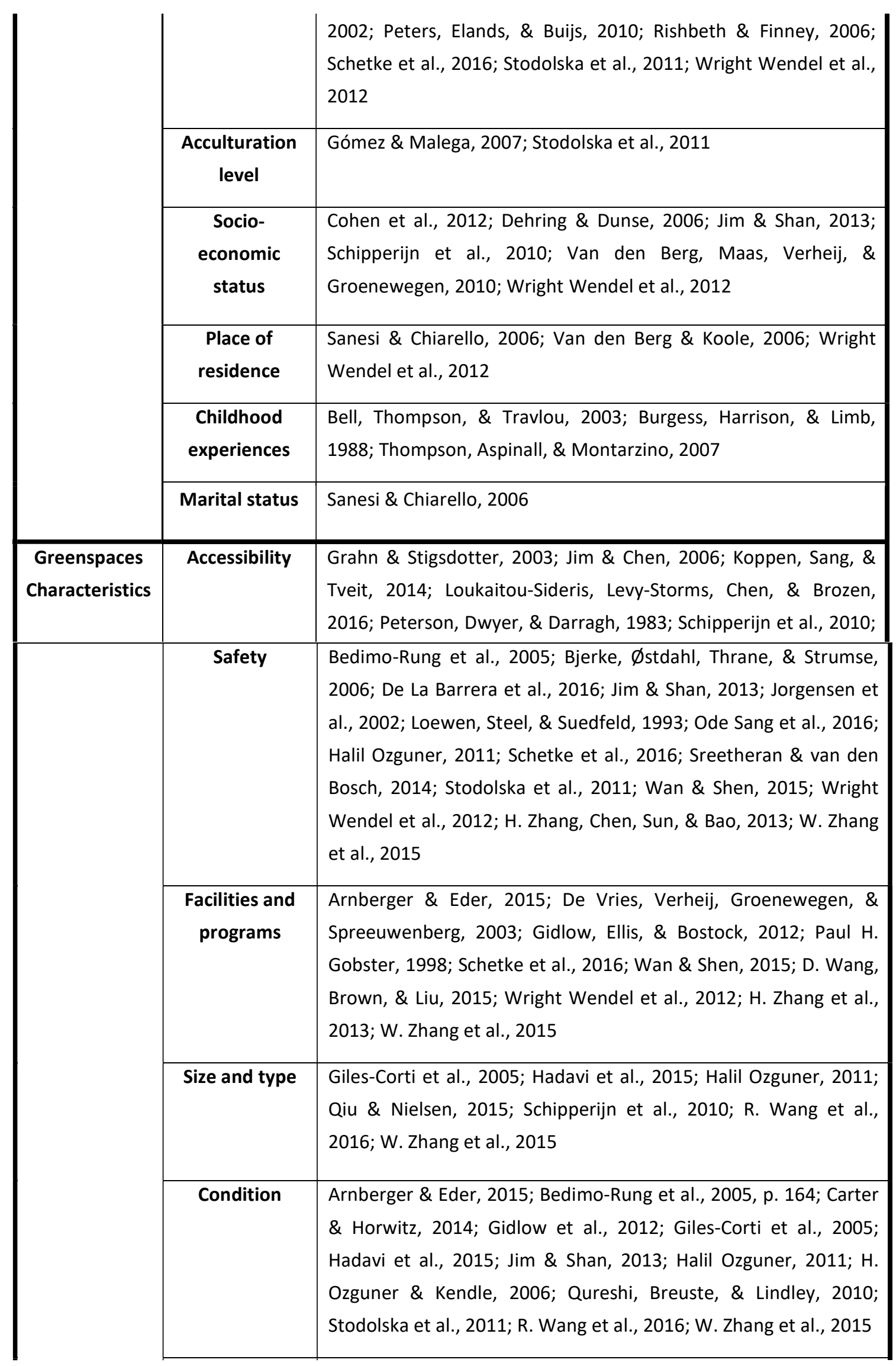




\begin{tabular}{|c|c|c|}
\hline & $\begin{array}{l}\text { Quality and } \\
\text { attractiveness }\end{array}$ & $\begin{array}{l}\text { Arnberger \& Eder, 2015; Bixler \& Floyd, 1997; Bjerke et al., 2006; } \\
\text { Giles-Corti et al., 2005; Paul H Gobster \& Westphal, 2004; } \\
\text { Jansson, Fors, Lindgren, \& Wistrom, 2013; Ode et al., 2009; Ode } \\
\text { Sang et al., 2016, p. 268; H. Ozguner \& Kendle, 2006; Tzoulas \& } \\
\text { James, 2010; Van den Berg, Jorgensen, \& Wilson, 2014; Wan \& } \\
\text { Shen, 2015; W. Zhang et al., } 2015\end{array}$ \\
\hline & Walkability & $\begin{array}{l}\text { Arnberger \& Eder, 2015; Giles-Corti et al., 2005; D. Wang, Brown, } \\
\text { Liu, et al., 2015; H. Zhang et al., 2013; W. Zhang et al., } 2015\end{array}$ \\
\hline & Biodiversity & Qiu, Lindberg, \& Nielsen, 2013; Qiu \& Nielsen, 2015 \\
\hline $\begin{array}{l}\text { Perception of } \\
\text { greenspaces }\end{array}$ & $\begin{array}{l}\text { Perceived } \\
\text { sensory } \\
\text { dimensions }\end{array}$ & $\begin{array}{l}\text { Grahn \& Stigsdotter, 2010; Peschardt \& Stigsdotter, 2013; Qiu \& } \\
\text { Nielsen, } 2015\end{array}$ \\
\hline & $\begin{array}{c}\text { Visitors } \\
\text { attitude and } \\
\text { orientation }\end{array}$ & Lin et al., 2014; Rossi, Byrne, Pickering, \& Reser, 2015 \\
\hline & $\begin{array}{c}\text { Perceived } \\
\text { restorativeness }\end{array}$ & S. Kaplan, 1995; Peschardt \& Stigsdotter, 2013 \\
\hline & $\begin{array}{c}\text { Perceived } \\
\text { functionality }\end{array}$ & Sanesi \& Chiarello, 2006 \\
\hline & $\begin{array}{l}\text { Perceived } \\
\text { accessibility }\end{array}$ & D. Wang, Brown, Liu, et al., 2015 \\
\hline & $\begin{array}{l}\text { Perceived } \\
\text { safety }\end{array}$ & Jansson et al., 2013 \\
\hline $\begin{array}{l}\text { Preferences } \\
\text { for } \\
\text { greenspaces }\end{array}$ & $\begin{array}{l}\text { Type of } \\
\text { activities }\end{array}$ & $\begin{array}{l}\text { Loukaitou-Sideris, 1995; Ode Sang et al., 2016; Sanesi \& Chiarello, } \\
\text { 2006; Schetke et al., } 2016\end{array}$ \\
\hline
\end{tabular}




\section{Conclusions}

The multitude of benefits provided by greenspaces is mostly obtainable to residents who visit such spaces. There has been increasing interest among scholars and professionals in understanding residents' perceptions of and preferences for greenspaces and what encourages them to visit. However, there has been no consistent approach to using preferences or perceptions in the literature and both terms are used quite loosely. Therefore, the aim of this study was to gather, synthesise, and summarise the state of knowledge on greenspace perceptions and preferences from a set of online databases in order to inform both practice and research. A framework was developed to assist in this aim.

Based on a review of literature retrieved from three online databases and a snowballing technique, the framework was developed to show the linkages between perceptions and preferences and other qualities of greenspaces as well as individual characteristics. The framework included four main dimensions:
1) greenspace characteristics;
2) perceptions;
3) preferences; and
4) individual characteristics.

Drawing on the significance of each dimension, the framework brings perceptions and preferences studies together to manifest how they can be explored simultaneously.

The framework shows that preferences of greenspaces are usually determined by the individual characteristics, the type of activities and the characteristics of greenspaces, whereas perceptions of greenspaces are determined by individual characteristics, sensory dimensions and perceived qualities and the characteristics of greenspaces. Consequently, preferences of greenspaces seem to be related to the intended use and perceptions are more linked to the sensory experiences of greenspaces. Therefore, perceptions are more about existing conditions and the assessment of extant greenspaces, whereas preferences may be more relevant for a new design or an intervention in an existing greenspace. A more interdisciplinary approach and a simultaneous examination of perceptions of current greenspaces and residents' preferences for future developments is encouraged because it is likely to result in higher quality greenspaces that reflect residents' preferences and needs.

A better understanding of how greenspaces are experienced and used can impact the degree to which urban residents can benefit from such spaces. Therefore, the conceptual framework developed in this study can be used in future research on greenspaces and in tackling problems associated with urbanisation and enhancing residents' quality of life.

\section{References}

Adegun, O. B. (2018). Residents' relationship with green infrastructure in Cosmo City, Johannesburg. Journal of Urbanism: International Research on Placemaking and Urban Sustainability, 11(3), 329-346. DOI:10.1080/17549175.2018.1470103

Alcock, I., White, M. P., Wheeler, B. W., Fleming, L. E., \& Depledge, M. H. (2014). Longitudinal effects on mental health of moving to greener and less green urban areas. Environmental science \& technology, 48(2), 1247-1255.

Arnberger, A., \& Eder, R. (2015). Are urban visitors' general preferences for green-spaces similar to their preferences when seeking stress relief? Urban Forestry \& Urban Greening, 14(4), 872882. DOI:10.1016/j.ufug.2015.07.005

Bazeley, P., \& Richards, L. (2000). The NVivo qualitative project book: Sage. 
Bedimo-Rung, A. L., Mowen, A. J., \& Cohen, D. A. (2005). The significance of parks to physical activity and public health: a conceptual model. American journal of preventive medicine, 28(2), 159-168.

Bell, S., Thompson, C. W., \& Travlou, P. (2003). Contested views of freedom and control: children, teenagers and urban fringe woodlands in Central Scotland. Urban Forestry \& Urban Greening, 2(2), 87-100.

Bixler, R. D., \& Floyd, M. F. (1997). Nature is scary, disgusting, and uncomfortable. Environment and Behavior, 29(4), 443-467.

Bjerke, T., Østdahl, T., Thrane, C., \& Strumse, E. (2006). Vegetation density of urban parks and perceived appropriateness for recreation. Urban Forestry \& Urban Greening, 5(1), 35-44. DOI:10.1016/j. ufug.2006.01.006

Buchel, S., \& Frantzeskaki, N. (2015). Citizens' voice: A case study about perceived ecosystem services by urban park users in Rotterdam, the Netherlands. Ecosystem Services, 12, 169-177. DOI:10.1016/j. ecoser.2014.11.014

Buijs, A. E., Elands, B. H., \& Langers, F. (2009). No wilderness for immigrants: Cultural differences in images of nature and landscape preferences. Landscape and Urban Planning, 91(3), 113-123.

Burgess, J., Harrison, C. M., \& Limb, M. (1988). People, parks and the urban green: a study of popular meanings and values for open spaces in the city. Urban studies, 25(6), 455-473.

Carter, M., \& Horwitz, P. (2014). Beyond proximity: the importance of green space useability to self-reported health. Ecohealth, 11(3), 322-332. DOI:10.1007/s10393-014-0952-9
Caula, S., Hvenegaard, G. T., \& Marty, P. (2009). The influence of bird information, attitudes, and demographics on public preferences toward urban green spaces: The case of Montpellier, France. Urban Forestry \& Urban Greening, 8(2), 117-128.

Chen, B., Adimo, O. A., \& Bao, Z. (2009). Assessment of aesthetic quality and multiple functions of urban green space from the users' perspective: The case of Hangzhou Flower Garden, China. Landscape and Urban Planning, 93(1), 76-82. DOI:10.1016/j.landurbplan.2009.06.001

Cohen, D. A., Han, B., Derose, K. P., Williamson, S., Marsh, T., Rudick, J., \& McKenzie, T. L. (2012). Neighborhood poverty, park use, and park-based physical activity in a Southern California city. Social science \& medicine, 75(12), 2317-2325.

Conedera, M., Del Biaggio, A., Seeland, K., Moretti, M., \& Home, R. (2015). Residents' preferences and use of urban and peri-urban green spaces in a Swiss mountainous region of the Southern Alps. Urban Forestry \& Urban Greening, 14(1), 139147. DOI:10.1016/j.ufug.2015.01.003

De La Barrera, F., Reyes-Paecke, S., Harris, J., Bascuñán, D., \& Farías, J. M. (2016). People's perception influences on the use of green spaces in socioeconomically differentiated neighborhoods. Urban Forestry \& Urban Greening, 20, 254-264. DOI:10.1016/j.ufug.2016.09.007

De Vries, S., Verheij, R. A., Groenewegen, P. P., \& Spreeuwenberg, P. (2003). Naturalenvironmentshealthy environments? An exploratory analysis of the relationship between greenspace and health. Environment and planning A, 35(10), 1717-1731.

Dehring, C., \& Dunse, N. (2006). Housing density and the effect of proximity to public open space in Aberdeen, Scotland. Real Estate Economics, 34(4), 553-566. 
Douglas, O., Russell, P., \& Scott, M. (2018). Positive perceptions of green and open space as predictors of neighbourhood quality of life: implications for urban planning across the city region. Journal of Environmental Planning and Management, 1-21. DOI:10.1080/09640568.2018.1439573

Edwards, D., \& Weldon, S. (2006). Race equality and the forestry commission. Final Report. Forest Research, Alice Holt.

Ellaway, A., \& Macintyre, S. (2001). Women in their place: gender and perceptions of neighbourhoods and health in the West of Scotland. In $M$. Stafford, S. Cummins, S. Macintyre, A. Ellaway, \& M. Marmot (Eds.), Gender differences in the associations between health and neighbourhood environment (Vol. 60, pp. 1681-1692).

Ezzy, D. (2013). Qualitative analysis: Routledge.

Farahani, L. M., \& Maller, C. (2018). Investigating Residents' Use and Perceptions of Informal Greenspaces: A Study of Stony Creek in Melbourne's West. Paper presented at the Conference: State of Australian Cities National Conference, 28-30 November 2017, Adelaide, South Australia.

Farahani, L. M., Maller, C., \& Phelan, K. (2018). Private Gardens as Urban Greenspaces: Can They Compensate for Poor Greenspace Access in Lower Socioeconomic Neighbourhoods?

Gidlow, C. J., Ellis, N. J., \& Bostock, S. (2012). Development of the Neighbourhood Green Space Tool (NGST). Landscape and Urban Planning, 106(4), 347-358. DOI:10.1016/j. landurbplan.2012.04.007

Giles-Corti, B., Broomhall, M. H., Knuiman, M., Collins, C., Douglas, K., Ng, K., . . . Donovan, R. J. (2005). Increasing walking: how important is distance to, attractiveness, and size of public open space? American journal of preventive medicine, 28(2), 169-176.
Gobster, P. H. (1998). Urban parks as green walls or green magnets? Interracial relations in neighborhood boundary parks. Landscape and Urban Planning, 41(1), 43-55. DOI:http://dx.doi. org/10.1016/S0169-2046(98)00045-0

Gobster, P. H., \& Westphal, L. M. (2004). The human dimensions of urban greenways: planning for recreation and related experiences. Landscape and Urban Planning, 68(2), 147-165.

Gómez, E., \& Malega, R. (2007). Residential attributes, park use, and perceived benefits: An exploration of individual and neighbourhood characteristics. Leisure/Loisir, 31(1), 77-104.

Grahn, P., \& Stigsdotter, U. A. (2003). Landscape planning and stress. Urban Forestry \& Urban Greening, 2(1), 1-18.

Grahn, P., \& Stigsdotter, U. K. (2010). The relation between perceived sensory dimensions of urban green space and stress restoration. Landscape and Urban Planning, 94(3-4), 264-275. DOI:10.1016/j. landurbplan.2009.10.012

Gramann, J. H., Floyd, M. F., \& Saenz, R. (1993). Outdoor recreation and Mexican American ethnicity: A benefits perspective. Culture, conflict, and communication in the wildland-urban interface, 69-84.

Groenewegen, P. P., Van den Berg, A. E., De Vries, S., \& Verheij, R. A. (2006). Vitamin G: effects of green space on health, well-being, and social safety. BMC public health, 6(1), 1.

Hadavi, S., Kaplan, R., \& Hunter, M. C. R. (2015). Environmental affordances: A practical approach for design of nearby outdoor settings in urban residential areas. Landscape and Urban Planning, 134, 19-32. DOI:10.1016/j. landurbplan.2014.10.001 
Hitchings, R. (2013). Studying the preoccupations that prevent people from going into green space. Landscape and Urban Planning, 118, 98-102.

Jansson, M., Fors, H., Lindgren, T., \& Wistrom, B. (2013). Perceived personal safety in relation to urban woodland vegetation-A review. Urban Forestry \& Urban Greening, 12(2), 127-133.

Jay, M., \& Schraml, U. (2009). Understanding the role of urban forests for migrants-uses, perception and integrative potential. Urban Forestry \& Urban Greening, 8(4), 283-294.

Jay, M., \& Schraml, U. (2014). Diversity in mind: Towards a differentiated understanding of migrants' recreational practices in urban forests. Urban Forestry \& Urban Greening, 13(1), 38-47.

Jim, C. Y., \& Chen, W. Y. (2006). Perception and attitude of residents toward urban green spaces in Guangzhou (China). Environ Manage, 38(3), 338-349. DOI:10.1007/s00267-005-0166-6

Jim, C. Y., \& Shan, X. (2013). Socioeconomic effect on perception of urban green spaces in Guangzhou, China. Cities, 31, 123-131. DOI:10.1016/j. cities.2012.06.017

Jorgensen, A., Hitchmough, J., \& Calvert, T. (2002). Woodland spaces and edges: their impact on perception of safety and preference. Landscape and Urban Planning, 60(3), 135-150.

Kabisch, N., Qureshi, S., \& Haase, D. (2015). Humanenvironment interactions in urban green spaces - A systematic review of contemporary issues and prospects for future research. Environmental Impact Assessment Review, 50, 25-34. DOI:10.1016/j.eiar.2014.08.007

Kaczynski, A. T., Potwarka, L. R., Smale, B. J., \& Havitz, M. E. (2009). Association of parkland proximity with neighborhood and park-based physical activity: variations by gender and age. Leisure Sciences, 31(2), 174-191.
Kaplan, R., \& Kaplan, S. (1989). The experience of nature: A psychological perspective: CUP Archive.

Kaplan, S. (1995). The restorative benefits of nature: Toward an integrative framework. Journal of Environmental Psychology, 15(3), 169-182.

Keith, S. J., Larson, L. R., Shafer, C. S., Hallo, J. C., \& Fernandez, M. (2018). Greenway use and preferences in diverse urban communities: Implications for trail design and management. Landscape and Urban Planning, 172, 47-59. DOI:https://doi.org/10.1016/j. landurbplan.2017.12.007

Kemperman, A. D., \& Timmermans, H. J. (2006). Preferences, benefits, and park visits: A latent class segmentation analysis. Tourism analysis, 11(4), 221-230.

Kendal, D., Williams, N. S., \& Williams, K. J. (2012). Drivers of diversity and tree cover in gardens, parks and streetscapes in an Australian city. Urban Forestry \& Urban Greening, 11(3), 257-265.

Keniger, L. E., Gaston, K. J., Irvine, K. N., \& Fuller, R. A. (2013). What are the benefits of interacting with nature? Int J Environ Res Public Health, 10(3), 913-935. DOI:10.3390/ijerph10030913

Kienast, F., Degenhardt, B., Weilenmann, B., Wäger, Y., \& Buchecker, M. (2012). GIS-assisted mapping of landscape suitability for nearby recreation. Landscape and Urban Planning, 105(4), 385-399.

Kong, F., Yin, H., Nakagoshi, N., \& Zong, Y. (2010). Urban green space network development for biodiversity conservation: Identification based on graph theory and gravity modeling. Landscape and Urban Planning, 95(1), 16-27.

Koppen, G., Sang, Å. O., \& Tveit, M. S. (2014). Managing the potential for outdoor recreation: Adequate mapping and measuring of accessibility to urban recreational landscapes. Urban Forestry \& Urban Greening, 13(1), 71-83. 
Lee, A. C., \& Maheswaran, R. (2011). The health benefits of urban green spaces: a review of the evidence. Journal of public health, 33(2), 212-222.

Lin, B., Fuller, R. A., Bush, R., Gaston, K. J., \& Shanahan, D. F. (2014). Opportunity or orientation? Who uses urban parks and why. PLoS one, 9(1), e87422.

Loewen, L. J., Steel, G. D., \& Suedfeld, P. (1993). Perceived safety from crime in the urban environment. Journal of Environmental Psychology, 13(4), 323-331.

Loukaitou-Sideris, A. (1995). Urban form and social context: cultural differentiation in the uses of urban parks. Journal of Planning Education and Research, 14(2), 89-102.

Loukaitou-Sideris, A., Levy-Storms, L., Chen, L., \& Brozen, M. (2016). Parks for an Aging Population: Needs and Preferences of Low-Income Seniors in Los Angeles. Journal of the American Planning Association, 82(3), 236-251. DOI:10.1080/019443 63.2016.1163238

Madureira, H., Nunes, F., Oliveira, J. V., Cormier, L., \& Madureira, T. (2015). Urban residents' beliefs concerning green space benefits in four cities in France and Portugal. Urban Forestry \& Urban Greening, 14(1), 56-64. DOI:10.1016/j. ufug.2014.11.008

Maller, C., \& Farahani, L. (2018). Snakes in the city: understanding urban residents' responses to greening interventions for biodiversity. Paper presented at the Conference: State of Australian Cities National Conference, 28-30 November 2017, Adelaide, South Australia.

Marcus, C. C., \& Francis, C. (1997). People places: Design guidlines for urban open space: John Wiley \& Sons.

Mowen, A. J., Payne, L. L., \& Scott, D. (2005). Change and stability in park visitation constraints revisited. Leisure Sciences, 27(2), 191-204.
Ode, A., Fry, G., Tveit, M. S., Messager, P., \& Miller, D. (2009). Indicators of perceived naturalness as drivers of landscape preference. Journal of environmental management, 90(1), 375-383.

Ode Sang, Å., Knez, I., Gunnarsson, B., \& Hedblom, M. (2016). The effects of naturalness, gender, and age on how urban green space is perceived and used. Urban Forestry \& Urban Greening, 18, 268276. DOI:10.1016/j.ufug.2016.06.008

Ozguner, H. (2011). Cultural Differences in Attitudes towards Urban Parks and Green Spaces. Landscape Research, 36(5), 599-620. DOI:10.108 0/01426397.2011.560474

Ozguner, H., \& Kendle, A. D. (2006). Public attitudes towards naturalistic versus designed landscapes in the city of Sheffield (UK). Landscape and Urban Planning, 74(2), 139-157. DOI:10.1016/j. landurbplan.2004.10.003

Payne, L. L., Mowen, A. J., \& Orsega-Smith, E. (2002). An examination of park preferences and behaviors among urban residents: the role of residential location, race, and age. Leisure Sciences, 24(2), 181-198.

Peschardt, K. K., \& Stigsdotter, U. K. (2013). Associations between park characteristics and perceived restorativeness of small public urban green spaces. Landscape and Urban Planning, 112, 26-39. DOI:10.1016/j.landurbplan.2012.12.013

Peters, K., Elands, B., \& Buijs, A. (2010). Social interactions in urban parks: Stimulating social cohesion? Urban Forestry \& Urban Greening, 9(2), 93-100.

Peterson, G. L., Dwyer, J. F., \& Darragh, A. J. (1983). A behavioral urban recreation site choice model. Leisure Sciences, 6(1), 61-81. 
Pillay, S., \& Pahlad, R. (2014). A gendered analysis of community perceptions and attitudes towards green spaces in a Durban Metropolitan residential area: Implications for climate change mitigation. Agenda, 28(3), 168-178.

Qiu, L., Lindberg, S., \& Nielsen, A. B. (2013). Is biodiversity attractive?-On-site perception of recreational and biodiversity values in urban green space. Landscape and Urban Planning, 119, 136-146. DOI:10.1016/j.landurbplan.2013.07.007

Qiu, L., \& Nielsen, A. B. (2015). Are Perceived Sensory Dimensions a Reliable Tool for Urban Green Space Assessment and Planning? Landscape Research, 40(7), 834-854. DOI:10.1080/01426397.2015.10 29445

Qureshi, S., Breuste, J. H., \& Jim, C. (2013). Differential community and the perception of urban green spaces and their contents in the megacity of Karachi, Pakistan. Urban Ecosystems, 16(4), 853870.

Qureshi, S., Breuste, J. H., \& Lindley, S. J. (2010). Green space functionality along an urban gradient in Karachi, Pakistan: a socio-ecological study. Human Ecology, 38(2), 283-294.

Rishbeth, C., \& Finney, N. (2006). Novelty and nostalgia in urban greenspace: refugee perspectives. Tijdschrift voor economische en sociale geografie, 97(3), 281-295.

Rodiek, S. (2002). Influence of an outdoor garden on mood and stress in older persons. Journal of Therapeutic Horticulture, 13, 13-21.

Rossi, S. D., Byrne, J. A., Pickering, C. M., \& Reser, J. (2015). 'Seeing red'in national parks: How visitors' values affect perceptions and park experiences. Geoforum, 66, 41-52.
Sanesi, G., \& Chiarello, F. (2006). Residents and urban green spaces: The case of Bari. Urban Forestry \& Urban Greening, 4(3-4), 125-134. DOI:10.1016/j. ufug.2005.12.001

Schetke, S., Qureshi, S., Lautenbach, S., \& Kabisch, N. (2016). What determines the use of urban green spaces in highly urbanized areas? - Examples from two fast growing Asian cities. Urban Forestry \& Urban Greening, 16, 150-159. DOI:10.1016/j. ufug.2016.02.009

Schipperijn, J., Stigsdotter, U. K., Randrup, T. B., \& Troelsen, J. (2010). Influences on the use of urban green space - A case study in Odense, Denmark. Urban Forestry \& Urban Greening, 9(1), 25-32. DOI:10.1016/j.ufug.2009.09.002

Scott, A. (2003). Assessing Public Perception of Landscape: From Practice to Policy. Journal of Environmental Policy \& Planning, 5(2), 123-144. DOI:10.1080/1523908032000121193

Shackleton, C. M., \& Blair, A. (2013). Perceptions and use of public green space is influenced by its relative abundance in two small towns in South Africa. Landscape and Urban Planning, 113, 104112. DOI:10.1016/j.landurbplan.2013.01.011

Shanahan, D., Lin, B., Bush, R., Gaston, K. J., Dean, J. H., Barber, E., \& Fuller, R. A. (2015). Toward improved public health outcomes from urban nature. American journal of public health, 105(3), 470-477.

Smith, R. M., Thompson, K., Hodgson, J. G., Warren, P. H., \& Gaston, K. J. (2006). Urban domestic gardens (IX): composition and richness of the vascular plant flora, and implications for native biodiversity. Biological conservation, 129(3), 312322.

Sreetheran, M., \& van den Bosch, C. C. K. (2014). A socio-ecological exploration of fear of crime in urban green spaces-A systematic review. Urban Forestry \& Urban Greening, 13(1), 1-18. 
Stodolska, M., Shinew, K. J., Acevedo, J. C., \& Izenstark, D. (2011). Perceptions of Urban Parks as Havens and Contested Terrains by MexicanAmericans in Chicago Neighborhoods. Leisure Sciences, 33(2), 103-126. DOI:10.1080/01490400 .2011 .550220

Swanwick, C. (2009). Society's attitudes to and preferences for land and landscape. Land Use Policy, 26, S62-S75. DOI:10.1016/j. landusepol.2009.08.025

Talbot, J. F., \& Kaplan, R. (1991). The benefits of nearby nature for elderly apartment residents. The International Journal of Aging and Human Development, 33(2), 119-130.

Thompson, C. W., Aspinall, P., \& Montarzino, A. (2007). The childhood factor: Adult visits to green places and the significance of childhood experience. Environment and Behavior.

Townsend, M., Maller, C., St Leger, L., \& Brown, P. (2003). Using environmental interventions to create sustainable solutions to problems to health and wellbeing. Environmental health, 3(1), 58-69.

Tyrvainen, L. (1997). The amenity value of the urban forest: an application of the hedonic pricing method. Landscape and Urban Planning, 37(3), 211-222.

Tzoulas, K., \& James, P. (2010). Peoples' use of, and concerns about, green space networks: A case study of Birchwood, Warrington New Town, UK. Urban Forestry \& Urban Greening, 9(2), 121-128. DOI:10.1016/j.ufug.2009.12.001

United Nations. (2014). World Urbanization Prospects: The 2014 Revision, Highlights. Department of Economic and Social Affairs. Population Division, United Nations.
Van den Berg, A. E., Jorgensen, A., \& Wilson, E. R. (2014). Evaluating restoration in urban green spaces: Does setting type make a difference? Landscape and Urban Planning, 127, 173-181.

Van den Berg, A. E., \& Koole, S. L. (2006). New wilderness in the Netherlands: An investigation of visual preferences for nature development landscapes. Landscape and Urban Planning, 78(4), 362-372.

Van den Berg, A. E., Maas, J., Verheij, R. A., \& Groenewegen, P. P. (2010). Green space as a buffer between stressful life events and health. Social science \& medicine, 70(8), 1203-1210.

Wan, C., \& Shen, G. Q. (2015). Encouraging the use of urban green space: The mediating role of attitude, perceived usefulness and perceived behavioural control. Habitat International, 50, 130-139. DOI:10.1016/j.habitatint.2015.08.010

Wang, D., Brown, G., \& Liu, Y. (2015). The physical and non-physical factors that influence perceived access to urban parks. Landscape and Urban Planning, 133, 53-66. DOI:10.1016/j. landurbplan.2014.09.007

Wang, D., Brown, G., Liu, Y., \& Mateo-Babiano, I. (2015). A comparison of perceived and geographic access to predict urban park use. Cities, 42, 85-96. DOI:10.1016/j.cities.2014.10.003

Wang, R., Zhao, J., \& Liu, Z. (2016). Consensus in visual preferences: The effects of aesthetic quality and landscape types. Urban Forestry \& Urban Greening, 20, 210-217. DOI:10.1016/j. ufug.2016.09.005

Wright Wendel, H. E., Zarger, R. K., \& Mihelcic, J. R. (2012). Accessibility and usability: Green space preferences, perceptions, and barriers in a rapidly urbanizing city in Latin America. Landscape and Urban Planning, 107(3), 272-282. DOI:10.1016/j. landurbplan.2012.06.003 
Zhang, H., Chen, B., Sun, Z., \& Bao, Z. (2013). Landscape perception and recreation needs in urban green space in Fuyang, Hangzhou, China. Urban Forestry \& Urban Greening, 12(1), 44-52. DOI:10.1016/j.ufug.2012.11.001

Zhang, W., Yang, J., Ma, L., \& Huang, C. (2015). Factors affecting the use of urban green spaces for physical activities: Views of young urban residents in Beijing. Urban Forestry \& Urban Greening, 14(4), 851-857. DOI:10.1016/j.ufug.2015.08.006 